\title{
PERKEMBANGAN RUANG LINGKUP ANTROPOLOGI HUKUM
}

\author{
Dede Syah Putra \\ Email : dedesyahputra66@gmail.com \\ No BP: 1710003600237 \\ Universitas Ekasakti Padang
}

\section{A. PENDAHULUAN}

Antropologi secara etimologis berasal dari bahasa Yunani. Kata Anthropos berarti manusia dan logos berarti ilmu pengetahuan. Jadi, antropologi adalah ilmu yang mempelajari manusia. Oleh karena itu antropologi di dasarkan pada kemajuan yang telah dicapai ilmu pengetahuan sebelumnya.

Dalam Kamus Besar Bahasa Indonesia (KBBI) yang diterbitkan oleh Balai Pustaka, antropologi diartikan sebagai ilmu tentang manusia khususnya tentang asal-usul, aneka warna bentuk fisik, adat istiadat, dan kepercayaannya pada masa lampau. Antropologi hukum (dengan beberapa pengecualian yang sangat jarang) menghindari prasangka etnosentris.

Dalam ilmu antropologi hukum dipelajari juga mengenai peran, status atau kedudukan, nilai, norma dan juga budaya atau kebudayaan. Semua ini mencakup hal-hal yang sangat erat kaitannya dengan ilmu antropologi hukum. Antropologi hukum mempelajari masyarakat secara komparatif tanpa memperhatikan "primitif" atau "berbudaya", dan tidak membeda-bedakan secara kualitatif demi mendukung satu jenis masyarakat manusia dan menentang jenis masyarakat manusia dan menentang jenis masyarakat manusia yang lain. Bertolak belakang dangan beberapa ilmu sosial lainnya, antropologi hukum tidak dengan semena-mena memisahkan satu segmen seperti perekonomian, struktur politik, hukum, struktur kepribadian, atau "hubungan sosial" dari 
kebudayaan manusia, tetapi memahami dan mempelajari kebudayaan manusia sebagai satu keseluruhan yang saling berkaitan. Antropologi hukum adalah sebuah ilmu hukum sehingga memiliki sifat empiris. Teori harus didukung fakta atau setidaknya ada sampel yang representatif terhadap semua fakta.

Hukum menurut antropologi mempelajari hubungan perilaku manusia dengan sistem atau budaya yaitu :

1. Nilai : kumpulan atau himpunan tingkah laku baik dan buruk.

2. Norma : ukuran sikap atau perilaku wajar atau menyimpang.

3. Kaidah : dalil atau rumusan juga dapat diartikan sebagai keseluruhan nilai, norma.

4. Kebiasaan : aturan yang berasal dari hukum tradisional dan hukum modern.

Fase perkembangan tema studi antropologi hukum kearah mekanisme mekanisme penyelesaian sengketa seperti disebutkan oleh F.von Benda-Beckmann (1989) sebagai fase the anthropologhy of dispute settlements. Pada dekade tahun 1960-an tema studi studi antropologi lebih memberi perhatian pada fenomena kemajemukan hukum atau pluralisme hukum. Sejak tahun 1970-an tema studi antropologi hukum secara sistematis difokuskan pada hubungan antar institusi institusi penyelesaian sengketa secara tradisional, neo tradisional dan menurut institusi hukum negara. Fase selanjutnya studi pluralisme mekanisme penyelesaian sengketa mulai ditinggalkan, dan mulai diarahkan pada studi pluralisme hukum diluar penyelesaian sengketa, kemudian mulai difokuskan kepada mekanisme jaminan sosial (social security), pasar dan perdagangan, mekanisme irigasi pertanian, institusi koperasi dan perkreditan didaerah pedesaan di negara negara sedang berkembang. Di Indonesia sejak warsa 1980-an dunia pendidikan ilmu hukum mulai diperkaya dengan pengenalan studi studi hukum empiris dengan menggunakan pendekatan 
antropologis. Karena itu T.O Ihromi dan Valerine J.L Kriefhoff dari UI bekerjasama dengan F.Von Benda Beckmann dari Wageningen Agriculture University The Netherlands dapat dinobatkan sebagai peletak dasar studi antropologis tentang hukum yang kemudian dikenal sebagai Antropologi Hukum.

\section{B. PEMBAHASAN}

Ruang Lingkup Antropologi Hukum

Bagi seorang antropologi, suatu gejala hukum timbul, apabila ada kelakuan yang sedemikian rupa sehingga dibiarkan akan mengganggu atau bahkan merusak lembaga lembaga yang paling dihargai oleh warga masyarakat. Oleh karena itu, hukum sebagai aspek kebudayaan, mempunyai beberapa fungsi fundamental untuk memelihara kedudukan dalam masyarakat. Dalam hal ini telah dijelaskan oleh E.A. Hoebel, yaitu :

1. Merumuskan pedoman bagaimana warga masyarkat seharusnya berperikelakuan, sehingga terjadi integrasi minimal dalam masyarakat.

2. Menetralisasikan kekuatan dalam masyarakat, sehingga dapat dimanfaatkan untuk mengadakan ketertiban.

3. Mengatasi persengketaan, agar keadaan semula pulih kembali.

4. Merumuskan kembali pedoman yang mengatur hubungan antara warga masyarakat dan kelompok-kelompok, apabila terjadi berbagai perubahan.

Berdasarkan hal tersebut, ruang lingkup antropologi hukum hendaknya dikaitkan dengan beberapa fungsi hukum, yaitu sarana pengendalian sosial, sarana untuk memperlancar interaksi sosial, dan sarana pembaruan. 
Antropologi berhubungan dengan hukum adat, sosiologi, etnologi, religi, psikologi sosial 4 cara metode mempelajari antropologi hukum yaitu histonis, non matif eksploratif, deskriktif perilaku, studi kasus.

\section{Antropologi Fisik}

Antropologi fisik mempelajari manusia sebagai organisme biologis yang melacak perkembangan manusia menurut evolusinya dan menyelidiki variasi biologisnya dalam berbagai jenis (spesies). Contoh : Para antropologi umumnya memiliki anggapan bahwa nenek moyang manusia adalah sejenis kera dan monyet, karena memiliki kemiripankemiripan tertentu.

- Paleoantropologi

Merupakan ilmu tentang asal-usul atau soal terjadinya evolusi makhluk hidup manusia dengan mempergunakan bahan penelitian melalui sisa-sisa tubuh yang telah membatu, atau fosil-fosil manusia dari zaman ke zaman yang tersimpan dalam lapisan bumi dan didapat dengan berbagai penggalian.

- Antropologi Biologis

Merupakan bagian ilmu antropolgi yang mempelajari suatu pengertian tenteng sejarah terjadinya aneka warna makhluk manusia jika dipandang dari sudut ciri-ciri tubuhnya, baik lahir (fenotipik), seperti warna kulit, warna dan bentuk rambut, indeks tengkorak, bentuk muka, warna mata, bentuk hidung, tinggi badan dan bentuk tubuh maupun sifat bagian dalam (genotipik), seperti golongan darah dan sebagainya. Manusia dimuka bumi ini terdapat beberapa golongan berdasarkan persamaan mengenai beberapa ciri tubuh. Pengelompokkan seperti itu dalam ilmu antropologi disebut ras 


\section{Antropologi Budaya}

Antropologi Budaya memfokuskan perhatiannya pada kebudayaan manusia ataupun cara hidupnya dalam masyarakat. Menurut Haviland (1999:12) cabang antropologi budaya ini dibagi-bagi lagi menjadi tiga bagian, yakni antropologi prehistori, etnolinguistik, dan etnologi. Untuk memahami pekerjaan para ahli antropologi budaya, kita harus tahu tentang hakikat kebudayaan, menyangkut konsep kebudayaan, dan karakteristiknya; bahasa dan komunikasi, menyangkut hakikat bahasa dan bahasa dalam kerangka kebudayaan, serta kebudayaan dan kepribadian.

Antropologi budaya juga merupakan studi tentang praktik-praktik sosial, bentukbentuk ekspresif, dan penggunaan bahasa, dimana makna diciptakan dan diuji sebelum digunakan oleh masyarakat manusia.

- Antropologi prehistori

Merupakan ilmu tentang perkembangan dan penyebaran semua kebudayaan manusia sejak sebelum manusia mengenal tulisan atau huruf. Dalam ilmu sejarah, seluruh waktu dari perkembangan kebudayaan umat manusia mulai saat terjadinya mmakhluk manusia, yaitu kira-kira 800.000 tahun yang lalu hingga sekarang, dibagi menjadi dua bagian yakni masa sebelum mengenal tulisan atau huruf, dan masa setelah manusia mengenal tulisan atau huruf. Subilmu prehistori ini sering disebut ilmu arkeologi. Di sini ilmu arkeologi sebenarnya adalah sejarah kebudayaan dari zaman prehistori.

- Etnolinguistik atau Antropologi Linguistik

Suatu ilmu yang berkaitan dengan ilmu antropologi dengan berbagai metode analisis kebudayaan yang berupa daftar kata-kata, pelukisan tentang ciri dan tata bahasa 
dari beratus-ratus bahasa suku bangsa yang tersebar di berbagai tempat di muka bumi ini. Dari bahan ini telah berkembang ke berbagai macam metode analisis kebudayaan, serta berbagai metode untuk menganalisis dan mencatat bahasa-bahasa yang tidak mengenal tulisan. Semua bahan dan metode tersebut sekarang telah terolah, juga ilmu linguistic umum. Walaupun demikian, ilmu etnolinguistik di berbagai pusat ilmiah di dunia masih tetap berkaitan erat dengan ilmu antropologi, bahkan merupakan bagian dari ilmu antropologi.

- Etnologi

Merupakan bagian ilmu antropologi tentang asas-asas manusia, mempelajari kebudayaan-kebudayaan dalam kehidupan masyarakat dari bangsa-bangsa tertentu yang tersebar di muka bumi pada masa sekarang.

\section{Manfaat Antropologi}

a) Teoritis dapat mengetahui pengertian-pengertian hukum yang berlaku dalam masyarakat sederhana.

b) Dapat mengetahui masyarakat bisa mempertahankan nilai dasar yang dimiliki.

c) Dapat mengetahui perbedaan pendapat dan pandangan masyarakat atas waktu yang di tentukan.

d) Dapat mengetahui suku bangsa atau masyarakat yang masih kuat mempertahankan nilai budaya mereka.

e) Dapat mengetahui suku bangsa atau masyarakat norma-norma hukum yang masih tinggi. 
Tugas antropologi hukum adalah memberikan pemahaman tentang hukum-hukum monsteplaw yaitu memberikan kegiatan telaah yang kelak menjadi sistem seperti pembuat undang-undang. Sifat antropologi ada 2 yaitu:

1. Interdispliner yaitu saling membantu dan mendukung dalam menyelesaikan sesuatu

2. Interdependensi yaitu saling memiliki keterkaitan atau ketergantungan antara satu dengan lainnya.

Tiga pendekatan Antropologi Hukum dalam mengkaji hukum

1. Pendekatan Holistik (menyeluruh), yaitu mengaitkan antara fenomena hukum dengan aspek kebudayaan secara menyeluruh (POLEKSOSBUDHUAG),

2. Pendekatan Legal Centralism Approach, yaitu pendekatan secara terpusat.

3. Pendekatan Comparative Method, yaitu dengan melakukan studi perbandingan antara sistem-sistem hukum dalam masyarakat yang berbeda-beda di berbagai belahan dunia.

\section{PENUTUP}

Antropologi adalah ilmu yang mempelajari manusia. Oleh karena itu antropologi didasarkan pada kemajuan yang telah dicapai ilmu pengetahuan sebelumnya. Pengertian Antropologi dapat dilihat dari 2 sisi yaitu Antropologi sebagai ilmu pengetahuan artinya bahwa Antropologi merupakan kumpulan pengetahuan pengetahuan tentang kajian masyarakat dan kebudayaan yang disusun secara sistematis atas dasar pemikiran yang logis. Dan pengertian Antropologi yang kedua adalah cara-cara berpikir untuk mengungkapkan realitas sosial dan budaya yang ada dalam masyarakat dengan prosedur dan teori yang dapat dipertanggung jawabkan kebenarannya secara ilmiah. 
Setelah di kaji kita dapat mengemukakan hasilnya bahwa manfaat di dalam antropologi hukum sangat luas. Antropologi hukum telah memberikan kontribusi yang sangat besar bagi perkembangan ilmu hukum. Dan kesimpulan yang dapat diambil adalah dimana pun kita, kita tidak akan pernah jauh dari hukum selama kita berada di Negara hukum. Terkait dengan fungsi disiplin ilmu antropologi sendiri, menjadi hal unik untuk dikaji tentang sudut pandang antropologi yang membedakannya dengan antropologi hukum. Pada suatu perbandingan, jika antropologi hukum lebih menitikberatkan suatu budaya hukum yang berkaitan atau mempengaruhi masalah hukum (aspek yang melatar belakangi hukum dan penyelesaiaan hukum). Pada sudut pandang yang berbeda, antropologi memandang suatu fenoma sosial yang terjadi dimasyarakat dengan mengakitkan pada nilai, norma, adat, tradisi, dan budaya yang berada dikehidupan masyarakat tersebut. Antropologi menempatkan fungsinya sebagai disiplin ilmu yang memakai perspektif budaya (mengedepankan nilai-nilai budaya) dalam penyelesaian masalah kehidupan sosial manusia.

\section{DAFTAR PUSTAKA}

Darmini Roza dan Laurensius Arliman S, Peran Pemerintah Daerah Di Dalam Melindungi Hak Anak Di Indonesia, Masalah-Masalah Hukum, Volume 47, Nomor 1, 2018. https://doi.org/10.14710/mmh.47.1.2018.10-21

Laurensius Arliman S, Peranan Metodologi Penelitian Hukum di Dalam Perkembangan Ilmu Hukum di Indonesia, Soumatera Law Review, Volume 1, Nomor 1, 201. http://doi.org/10.22216/soumlaw.v1i1.3346.

Laurensius Arliman S, Peran Badan Permusyawaratan Desa di Dalam Pembangunan Desa dan Pengawasan Keuangan Desa, Padjadjaran Journal of Law, Volume 4, Nomor 3, 2017. https://doi.org/10.15408/jch.v4i2.3433.

Laurensius Arliman S, Penanaman Modal Asing Di Sumatera Barat Berdasarkan Undang- Undang Nomor 25 Tahun 2007 Tentang Penanaman Modal, Supremasi Hukum, Volume 1, Nomor 1, 2018. http://dx.doi.org/10.36441/hukum.v1i01.102 . 
Laurensius Arliman S, Memperkuat Kearifan Lokal Untuk Menangkal Intoleransi UmatBeragama Di Indonesia, Ensiklopedia of Journal, Volume 1, Nomor 1, 2018, https://doi.org/10.33559/eoj.v1i1.18.

Laurensius Arliman S, Perkawinan Antar Negara Di Indonesia Berdasarkan Hukum Perdata Internasional, Kertha Patrika, Volume 39, Nomor 3, 2017, https://doi.org/10.24843/KP.2017.v39.i03.p03.

Laurensius Arliman S, Partisipasi Masyarakat Di Dalam Pengelolaan Uang Desa PascaUndangUndang Nomor 6 Tahun 2014 Tentang Desa, Jurnal Arena Hukum, Volume 12, Nomor 2, 2019, https://doi.org/10.21776/ub.arenahukum.2019.01202.5.

Laurensius Arliman S, Mewujudkan Penegakan Hukum Yang Baik Di Negara Hukum Indonesia, Dialogica Jurnalica, Volume 11, Nomor 1, 2019, https://doi.org/10.28932/di.v11i1.1831.

Laurensius Arliman S, Mediasi Melalui Pendekatan Mufakat Sebagai Lembaga Alternatif Penyelesaian Sengketa Untuk Mendukung Pembangunan Ekonomi Nasional, UIR Law Review, Volume 2, Nomor 2, 2018, https://doi.org/10.25299/uirlrev.2018.vol2(02).1587

Laurensius Arliman S, Peranan Filsafat Hukum Dalam Perlindungan Hak Anak Yang Berkelanjutan Sebagai Bagian Dari Hak Asasi Manusia, Doctrinal, Volume 1, Nomor 2,2016 .

Laurensius Arliman S, Ni Putu Eka Dewi, Protection of Children and Women's Rights in Indonesiathrough International Regulation Ratification, Journal of Innovation, Creativity and Change Volume 15, Nomor 6, 2021.

Laurensius Arliman S, Gagalnya Perlindungan Anak Sebagai Salah Satu Bagian Dari Hak Asasi Manusia Oleh Orang Tua Ditinjau Dari Mazhab Utilitarianisme, Jurnal Yuridis, Volume 3, Nomor 2, 2016, http://dx.doi.org/10.35586/.v3i2.180.

Laurensius Arliman S, Tantangan Pendidikan Kewarganegaraan Pada Revolusi 4.0, Jurnal Ensiklopedia Sosial Review, Volume 2, Nomor 3, 2020. 